\title{
Recent Approaches, Catalysts and Formulations for Enhanced Recovery of Heavy Crude Oils
}

\author{
Umar Gaya $a^{1,2 *}$ \\ ${ }^{1}$ Department of Pure and Industrial Chemistry, Faculty of Physical Sciences, Bayero University, 700241 Kano, 1 Gwarzo Road, \\ Nigeria \\ 2 Directorate of Science and Engineering Infrastructure, National Agency for Science and Engineering Infrastructure (NASENI), Idu \\ Industrial Layout, 900104 Garki, Abuja, Nigeria \\ * Corresponding author, e-mail: uigaya.chm@buk.edu.ng
}

Received: 20 September 2020, Accepted: 04 December 2020, Published online: 16 August 2021

\begin{abstract}
Crude oil deposits as light/heavy form all over the world. With the continued depletion of the conventional crude and reserves trending heavier, the interest to maximise heavy oil recovery continues to emerge in importance. Ordinarily, the traditional oil recovery stages leave behind a large amount of heavy oil trapped in porous reservoir structure, making the imperative of additional or enhanced oil recovery (EOR) technologies. Besides, the integration of downhole in-situ upgrading along with oil recovery techniques not only improves the efficiency of production but also the quality of the produced oil, avoiding several surface handling costs and processing challenges. In this review, we present an outline of chemical agents underpinning these enabling technologies with a focus on the current approaches, new formulations and future directions.
\end{abstract}

Keywords

in-situ upgrading, enhanced oil recovery, aquathermolysis, heavy oil, catalyst

\section{Introduction}

The world is caught up in the ever-increasing need for energy and reliance on fossil sources. In this scenario, the US accounted for $17.34 \%$ of the world's 2015 total primary energy consumption [1], with projections of the continued predominance of petroleum and other liquids over other renewable energy resources. In 2019, petrol and distillate fuel oil's share of the total transportation energy consumption reached a record $84 \%$ [2]. The predominance of proved heavy oil reserves, energy demand, and potential to yield as many hydrocarbons (HCs) as conventional oil resources ignite interest in heavy oil production [3].

Globally, oil reserves are mainly unconventional, in the form of heavy oil, extra-heavy oil, oil sand, tar sands, oil shale or bitumen [4], reaching up to six times the proven reserves of the conventional oil [5]. Basically, the term heavy oil has been variously defined by organisations such as the Alberta Energy Resources Conservation Board (AERCB), American Petroleum Institute (API), Canadian Centre for Energy (CCE), the United Nations Institute for Training and Research (UNITAR)/World Petroleum Congress (WPC), and the US Geological Survey (USGS) based on API gravity
Table 1 Selected definitions of heavy crude oil at $15^{\circ} \mathrm{C}$.

\begin{tabular}{lccc}
\hline Source & API $\left({ }^{\circ}\right)$ & Viscosity (mPa.s) & References \\
\hline CCE & $>10$ & $<10^{5}$ & {$[6]$} \\
AERCB & 10 to 19 & $10^{2}$ to $10^{5}$ & {$[7]$} \\
API & $<22.3$ & $>10$ & {$[6]$} \\
USGS & $<22$ & $>10^{2}$ & {$[8]$} \\
UNITAR/WPC & 10 to 20 & $10^{2}$ to $10^{5}$ & {$[9]$} \\
\hline
\end{tabular}

(which is specific gravity related) and viscosity, as displayed in Table 1. The UNITAR definition has been the most widely used over the decades. Even though sufficient for many purposes, this definition will not be complete without the mention of the high content of asphaltenes, waxes, carbon residue and an excessive amount of metals ( $\mathrm{V}, \mathrm{Ni}, \mathrm{Cu}, \mathrm{Fe})$, and non-metals $(\mathrm{N}$, and usually $>2 \% \mathrm{~S})$ in the heavy crude oil.

Various methods have been developed for the recovery and upgrading of such unconventional feedstocks [10]. The traditional primary recovery (which is based on the reservoir pressure) and the secondary (water or gas flooding) process (Fig. 1) can recover only $25-50 \%$ of the original oil in place (OOIP) $[11,12]$. A tertiary process called 
Steam injection well

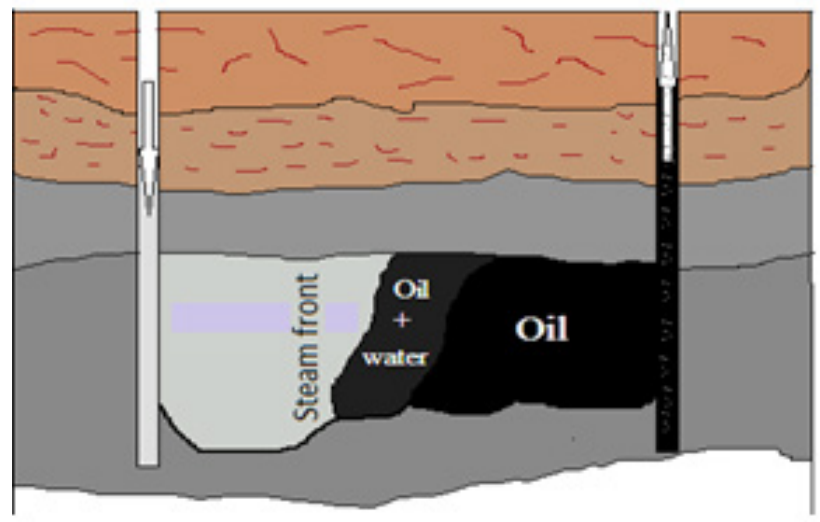

Fig. 1 Schematic diagram showing steam flooding the enhanced oil recovery (EOR) is necessary due to poor quality and production efficiency [13].

The EOR techniques (and their global usage) can be thermal $(10 \%)$, chemical (67\%), gaseous (10\%), and miscellaneous (3\%) [14]. In the chemical EOR, chemical agents are applied to improve sweep efficiency without any influence on the chemical properties of the oil, while in the thermal upgrading methods, catalysts have the potential to not only assist recovery but the overall quality of the oil for use. To overcome refining, logistical and cost challenges, interest has been geared towards combining heavy crude oil recovery with upgrading, and this has led to the emergence of new chemical formulations [15]. In this review, we undertake to present an update on the approaches to the exploitation of catalysts and chemical additives in chemical and thermal EOR and in-situ heavy oil upgrading.

\section{Chemical enhanced recovery methods}

Chemical enhanced oil recovery (CEOR) can improve recoveries from thin or deep oil reserves injection, especially where thermal methods cannot be applied. Based on the use of a single chemical agent, a mono-chemical CEOR may be alkaline (A), surfactant (S), polymer (P), solvent, $\mathrm{CO}_{2}$-based method, but a combination of two or more versions of these methods (AS, ASP etc.) have been commercially more successful. One important feature of all CEOR methods is that increase in oil is caused only via physical mechanism, necessitating the need for costlier handling and refining in order to produce lighter fractions.

\subsection{Alkaline flooding}

Alkaline flooding (A) is a relatively simple, cheaper, and more readily understood of all EOR processes. Lye/
$\mathrm{NaOH}$ and/or sodium salts $\left(\mathrm{Na}_{2} \mathrm{CO}_{3}, \mathrm{NaBO}_{2}\right.$, and sodium orthosilicate), injected into the reservoir, react with naphthenic acids to form a natural surfactant which drastically reduces the interfacial tension (IFT) at the oil-water interface. The efficiency of the process depends on concentration, alkali type, and whether it was used singly or with other substances. Polyphosphate, $\mathrm{NH}_{4} \mathrm{OH}$, and $\mathrm{Na}_{2} \mathrm{CO}_{3}$ are less efficient than $\mathrm{NaOH}$, whereas $\mathrm{Ca}(\mathrm{OH})_{2}$ and $\mathrm{Mg}(\mathrm{OH})_{2}$ do not significantly lower IFT [16]. Naphthenic acids are the major components of the total acid content of crude oil. Although they are popular corrodents in oil refineries, the water-soluble, low molecular weight-naphthenic acids (C8-C12) can readily form industrially-desirable sodium naphthenate as shown in chemical Scheme 1.

\subsection{Surfactant flooding}

Surfactant composes of lipophobic site to which a lipophilic site is attached. It may be anionic, cationic, nonionic or zwitterionic, depending upon the charge of its polar group. It is water-soluble if containing $<\mathrm{C} 12$ hydrocarbon (HC) chains attached to the lipophilic site. The anionic ones account for more than $70 \%$ of the surfactant market and can be used mostly with the cationic ones as wettability agents [17]. They work by generating form or emulsion in water which reduces surface tension. However, at neutral $\mathrm{pH}$ these reservoirs tend to be negatively charged, favouring the adsorption of anionic surfactants. Variants with large hydrophobes, low retention, and compatibility with specific crude and conditions are therefore desirable [18]. A list of selected surfactants used in CEOR is given in Table 2.

A prominent disadvantage of surfactant flooding (S) is that it is capital intensive, requires laborious operation test cycles [24] and uses mostly environmentally unfriendly surfactants [25]. These reasons caused a decline in surfactant injection from nearly $10 \%$ (in the 1970 s and the 80 s) to $0.5 \%$ in the $90 \mathrm{~s}$ [26], and renewed interest in environmentally benign EOR chemicals [27].

\subsection{Polymer flooding}

Polymer flooding $(\mathrm{P})$ is the most widely applied EOR for more than five decades. The first successful application on heavy-oil was the Canadian Pelikan Lake reservoir [28].

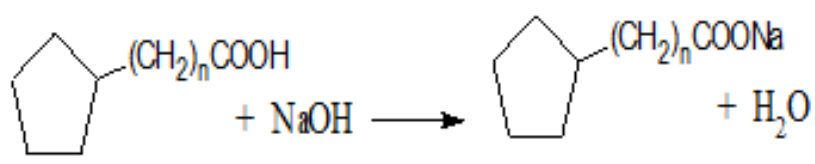

Scheme 1 Esterification of crude oil-based naphthenic acids to useful naphthenates 
Table 2 Selected surfactant groups used in the oil recovery fields.

\begin{tabular}{|c|c|c|c|c|}
\hline $\begin{array}{l}\text { Surfactant } \\
\text { family }\end{array}$ & Description & Advantage & Disadvantage & References \\
\hline $\begin{array}{l}\text { 1. Alkyl aryl } \\
\text { sulphonates }\end{array}$ & $\begin{array}{l}\mathrm{A} \mathrm{C}_{9}-\mathrm{C}_{30} \text { alkyl benzene } \\
\text { sulphonate. }\end{array}$ & $\begin{array}{l}\text { 1. Stability and ability to be tailored } \\
\text { based on reservoir conditions. } \\
\text { 2. Availability of raw materials. }\end{array}$ & $\begin{array}{l}\text { 1. Unstable at high salinity. } \\
\text { 2. Non-biodegradable. } \\
\text { 3. Only the unconventional types (such } \\
\text { as those derived from alpha-olefin) can } \\
\text { recover highly waxy heavy oil. }\end{array}$ & {$[19,20]$} \\
\hline $\begin{array}{l}\text { 2. Sodium alkyl } \\
\text { sulphate (SDS) }\end{array}$ & $\begin{array}{l}\text { Anionic surfactants with } \\
\text { formula ROSO3Na, where } \\
\mathrm{R}=\text { hydrocarbon chain such } \\
\text { as dodecyl, octyl or lauryl }\end{array}$ & $\begin{array}{l}\text { 1. One of the most commonly } \\
\text { manufactured surfactant. } \\
\text { 2. Synergy with hydrophobic modified } \\
\text { silica for increased temperature } \\
\text { tolerance. }\end{array}$ & $\begin{array}{l}\text { 1. Toxic and non-biodegradable. } \\
\text { 2. Insoluble in water at high } \\
\text { temperature. }\end{array}$ & {$[21]$} \\
\hline $\begin{array}{l}\text { 3. Alkyl-olefin } \\
\text { sulphonates } \\
\text { (AOS) }\end{array}$ & $\begin{array}{l}\mathrm{R}-\mathrm{CH}=\mathrm{CH}\left(\mathrm{CH}_{2}\right) \mathrm{nSO}_{3} \mathrm{Na} \text {, } \\
\text { where } \mathrm{R}=\mathrm{C}_{10} \text { to } \mathrm{C}_{20} \text {, usually } \\
\mathrm{C}_{14}-\mathrm{C}_{20} \text { alkene, alkane or } \\
\text { substituted alkane. }\end{array}$ & $\begin{array}{l}\text { 1. One of the most commonly } \\
\text { manufactured surfactant. } \\
\text { 2. Used as foaming agent. } \\
\text { 3. Stability at steam temperatures. }\end{array}$ & & \\
\hline $\begin{array}{l}\text { 4. Linear alkyl } \\
\text { benzene (LAB) } \\
\text { sulphonates }\end{array}$ & $\begin{array}{l}\text { Organic compounds with } \\
\text { the formula } \mathrm{PhC}_{\mathrm{n}} \mathrm{H}_{2 \mathrm{n}+1} \text {, } \\
\text { where } \mathrm{n}=10 \text { to } 16 \text {. }\end{array}$ & & $\begin{array}{l}\text { 1. Perform better with crudes having } \\
\mathrm{C}_{7} \text { to } \mathrm{C}_{10} \\
\text { 2. Ecotoxicity }\end{array}$ & \\
\hline $\begin{array}{l}\text { 5. Alkyl } \\
\text { propoxy } \\
\text { sulphates }\end{array}$ & $\begin{array}{l}\text { Usually in the form of } \\
\mathrm{R}(\mathrm{PO}) \mathrm{OSO} 3 \mathrm{Na} \text {, where } \mathrm{PO}= \\
\text { propylene oxide and } \mathrm{R} \text { is an } \\
\text { etheryl moiety with }>\mathrm{C}_{12} .\end{array}$ & $\begin{array}{l}\text { 1. Show good performance. } \\
\text { 2. Have large hydrophobes. } \\
\text { 3. Suitable for tight carbonate reservoirs } \\
\text { Up to } 40 \% \text { additional recovery. }\end{array}$ & $\begin{array}{l}\text { 1. Commercial product not adequately } \\
\text { available. } \\
\text { 2. Not suitable for high temperature } \\
\text { application }\end{array}$ & {$[22]$} \\
\hline $\begin{array}{l}\text { 6. Alpha olefin } \\
\text { sulphates }\end{array}$ & $\begin{array}{l}\mathrm{ROSO}_{3} \mathrm{Na} \text {, where } \mathrm{R} \text { is an } \\
\text { olefinic chain within the } \\
\text { range of } \mathrm{C}_{14}-\mathrm{C}_{16} \text {. }\end{array}$ & $\begin{array}{l}\text { 1. Superior over many surfactants } \\
\text { including LAB sulphonates. } \\
\text { 2. Industrial products are available. } \\
\text { 3. Readily biodegradable. }\end{array}$ & $\begin{array}{l}\text { Not suitable for high-temperature } \\
\text { application }\end{array}$ & [23] \\
\hline
\end{tabular}

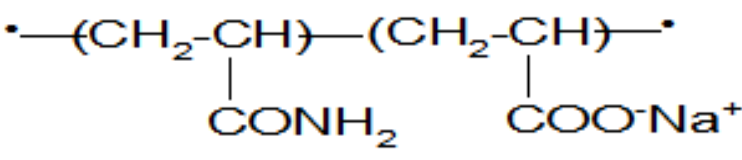

Scheme 2 Structural formula of traditional Xanthan

Basically, it involves the improvement of water injection profile, and reducing viscous fingering and water permeability relative to oil [29]. The traditional Xanthan (Scheme 2) is not as popular as the more soluble and cheaper, partially hydrolysed polyacrylamide (HPAM) (Scheme 3) [30]. Even though the HPAM is less tolerant to salinity, susceptible

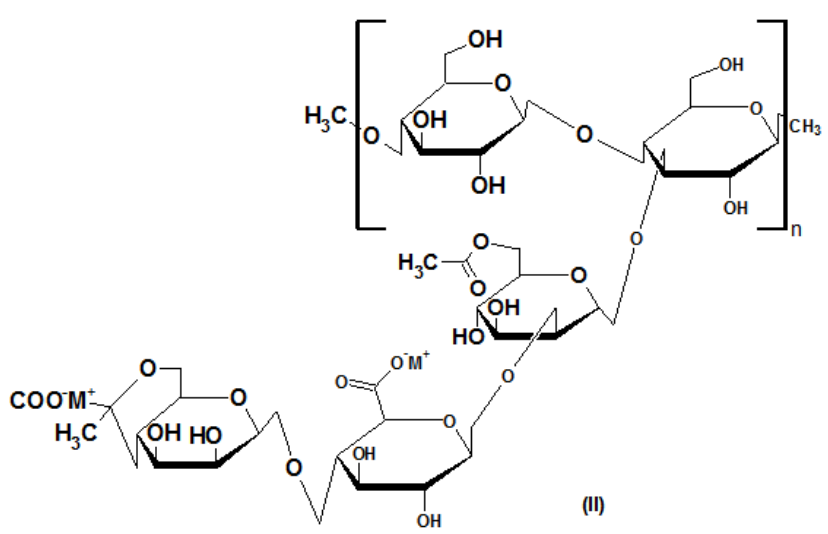

Scheme 3 Structural formula of partially hydrolysed polyacrylamide to alkaline hydrolysis and degradation at $>70{ }^{\circ} \mathrm{C}$, unlike Xanthan, it does not require a stabiliser against microbial degradation [31].

Polymer flooding produces lower additional oil, and due to cost and mechanical consideration of injection pressure, they are of little benefit for heavy oils with higher viscosities. The modification of the hydrophobicity of HPAM is among potential solutions to these problems [32]. A hydrophobically-modified terpolymer for example, can reduce viscosity at high salinity and temperature conditions, with the ability to dry up within $2 \mathrm{~h}$ [33].

\subsection{Combined methods}

Combined chemical flooding methods gives the beneficial effect of two or more classes of chemicals in CEOR. Whereas the technical feasibility of alkaline-surfactant flooding (AS) is still being assessed in laboratories and results are promising [34], surfactant-polymer flooding (SP) has demonstrated outstanding performance at low temperatures $\left(70\right.$ to $\left.120{ }^{\circ} \mathrm{C}\right)[35]$. However, one of the disadvantages of SP flooding is rapid sediment accumulation, forming multi-modal pores in conglomerate reservoirs [36]. Alkaline-surfactant-polymer flooding (ASP) will reduce the adsorption of expensive surfactants and 
expand the sweep efficiency [37] but as the concentration of $\mathrm{Ca}^{2+}$ and $\mathrm{Mg}^{2+}$ exceeds 10ths of $\mathrm{mg} / \mathrm{L}$, scaling takes place as shown in chemical Eq. (1). This problem can be mitigated by prior water-treatment, or by adopting surfactant-polymer flooding (SP), which in addition can prevent strong emulsification, and alkali corrosion [38]. For all surfactant-based methods however, the scarcity of highly-performing industrial surfactants, unsound pilot tests, and high technical risk has been a limiting factor [39].

$$
\mathrm{Na}_{2} \mathrm{CO}_{3}+\mathrm{Ca}^{2+} \rightarrow 2 \mathrm{Na}^{+}+\mathrm{CaCO}_{3}
$$

In the organic alkali-surfactant-polymer flooding (OASP), an organic alkali (OA) is applied to enhance sweep efficiency. A coreflooding study showed that a combination of ethanolamine as OA and SLPS can achieve $>20 \%$ increase in recovery [40], which is as a result of increased oil-in-water emulsification [41]. Recovery depends upon the properties of the oil, fluids, and formation interfaces such as wettability, contact angle, capillary forces, viscosity, and interfacial tension (IFT) [42]. Basically, interactions between reservoir minerals and surfactant/polymer may occur depending on the geology of the reservoir rocks, and this can affect interfacial properties such as surface charge and wettability. For certain additives, these interactions are not fully understood [43]. Consequently, the criteria for the application of a particular EOR is formation-dependent. On the whole, due to the high chemical consumption of the fractured carbonates at majority of the world's largest reservoirs [44] the application of AP and ASP is limited to sandstone reservoirs [45].

\subsection{Synergy with new formulations}

An array of chemical agents such as urea, terpolymers, binary mixtures, and monomers, has been examined for possible synergy with EOR chemicals [46-48]. Notably, the synergy between nano-sized crosslinked polymeric particles with low salinity water can lead to ultra-low interfacial tensions and huge ( $>62 \%)$ oil recovery [49]. In a study, the combination of poly(vinyl alcohol)-rhamonolipid and $\mathrm{NaOH}$-rhamonolipid-PVA in saline EOR medium was found to significantly reduce the surface tension and IFT [50]. Similarly, a polyacrylates/amorphous carbon thin film composite recovered $19.2 \%$ of residual oil saturation [51]. Some binary surfactant mixtures (such as polyoxyethylene ether carboxylate blended with a quaternary ammonium chloride) [52] as well as non-traditional CEOR chemical agents (such as nanopyroxenes) can also cooperatively and significantly improve oil recovery [53].
Experimental results showed that a binary mixture of cocamidopropyl hydroxysultaine and alcohol propoxy sulphate can outperform mixtures of zwitterionic, and anionic surfactants, with good oil displacement (63-75\%) and surfactant retention $(0.08 \mathrm{mg} / \mathrm{g})$ [54].

Certain ethoxylated nonionic surfactants (Scheme 4) have been proposed for limiting or even overcoming the retention of anionic sulphate or sulphonate surfactants, in carbonate and clayey reservoirs [55], where $\mathrm{m}$ is the number of propylene oxide units ( 0 to 20$), n$ is the number of ethylene oxide units usually greater than 20. Moreover, nonionic amines (compound Scheme 5; "A" = is alkylene, $\mathrm{R}=$ either $\mathrm{H}$ or alkyl, and $\mathrm{x}$ can be zero) with good chemical stability, thermal stability, low adsorption, high salinity tolerance, and a wide $\mathrm{pH}$ range, have been described [56]. Lastly, an efficient ASP injection of an extended sulphate surfactant of alkoxyated, alkyl propoxylated, or their combination and a co-surfactant (alkyl benzene sulphonate, internal olefin sulphonate, or their combination) has been reported [57]. Much as in the ASP, silica nanoparticles having a hydrophobic chain can reduce adsorption and IFT, and recover up to $15.74 \%$ oil $[58,59]$.

\section{Thermal enhanced recovery methods}

\subsection{Overview of the methods}

Over the past few decades, thermal methods accounted for nearly $70 \%$ of the world's EOR [60, 61]. Five thermal EORs are widely recognised, namely, the cyclic steam stimulation (CSS), steam-assisted gradient drainage (SAGD), steam and hot water flooding, steam/solvent hybrid system which all involve fluid injection, and in-situ combustion (ISC) or fire flooding. A schematic display of EOR methods is shown in Fig. 2. Newer injection approaches include the high pressure air injection (HPAI) (for deep, high pressure light oil reservoirs) and the use of an in-situ generated syngas $\left(\mathrm{H}_{2}\right.$ and $\left.\mathrm{CO}\right)$. The steam-assisted gradient drainage (SAGD) injects steam into the

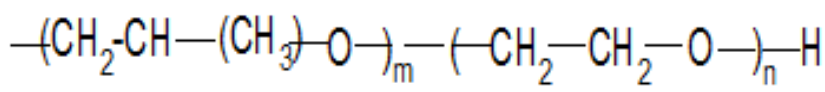

Scheme 4 Desorbing agents for enhanced oil recovery in carbonate or clayey reservoirs

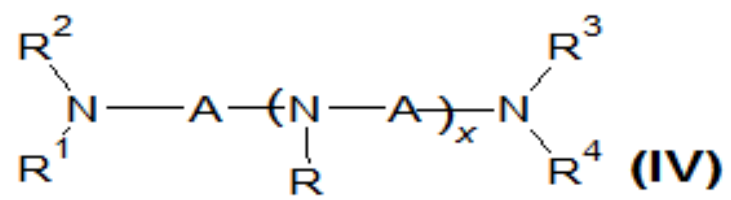

Scheme 5 Potent nonionic amines for exploitation in ASP. Substituents $\mathrm{A}$ and $\mathrm{R}$, and subscript $\mathrm{x}$ as described in the text 


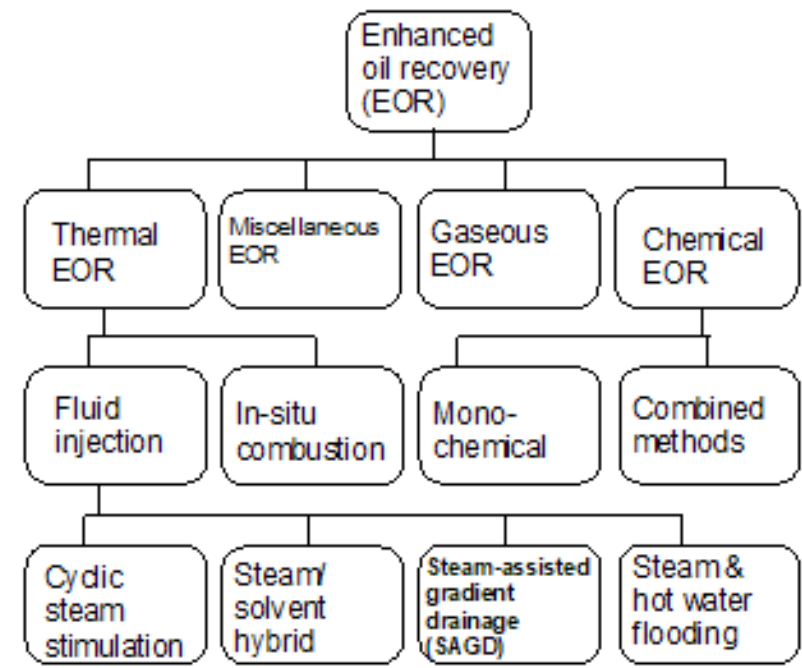

Fig. 2 Chemical and thermal enhanced recovery methods

heavy oil or bitumen reservoir via two horizontal wells, except in the vapour extraction (VAPEX) variant, which injects vaporized solvents. Cyclic steam stimulation (CSS) is also commonly used steam injection for the recovery of high viscosity oils. A successful steam EOR needs at least $20 \%$ porosity of the reservoir rock, at least $100 \mathrm{mD}$ permeability, $40 \%$ heavy oil saturation, at least $800 \mathrm{bbl}$ per acre-ft of oil content, reservoir depth of $<3000$ feet, and thickness of at least $30 \mathrm{ft}$ [62].

The ISC method uses vertical producer wells except in the toe-to-heal air injection (THAI) variant which consists of a combination of direct or staggered vertical injection (into which air is injected at 600 to $700{ }^{\circ} \mathrm{C}$ ) and horizontal producer wells [63]. Today, due to huge cost limitation and requirement of special operation conditions, only a few ISC operate. At present, a catalytic version of classical THAI known as the toe-to-heal air injection CAtalytic upgrading PRocess In-situ (THAI CAPRI) has been successfully performed [64].

\subsection{In-situ catalytic upgrading}

Heavy oil upgrading refers to the fractionation or chemical treatment of heavy oils that produces permanent changes in the physicochemical properties of these materials [9]. Considerable research interest has been geared into the use of catalysts and additives to upgrade heavy oil en route thermal recovery by the conventional SAGD, VAPEX, THAI, and CSS technologies. The THAI CAPRI was introduced in 1998 to avoid surface upgrading and mitigate the environmental impact of the heavy oil components. Primarily, the decision to upgrade depends partly on the physical properties of the oil and the cost of upgrading [65]. Because the main essence of upgrading is to increase sulphur-free, nitrogen-free and metal-free distillates, as well as $\mathrm{H} / \mathrm{C}$ ratio which typically stands at 1.5 [66], typical surface-based approaches for heavy oil upgrading involve carbon rejection (such as coking, thermal cracking, visbreaking), hydrogen addition (with slurry, fixed-bed, moving-bed, ebullated reactor), or their combination $[5,67]$. The traditional thermal conversion of heavy oil involves either pyrolysis, cracking (which may be catalytic or thermal-only), or hydrocracking to yield valuable distillates components [68]. The key reactions in upgrading have been detailed previously [6, 69].

In subsurface upgrading (SSU) the reservoir is made to act as a refinery, to liberate lighter products. Revolutionary, non-catalytic SSUs such as the Shell's in-situ upgrading process (IUP) and the NSolv, widely referred to as game-changers, have been successfully pilot-tested in the last decade. Each of these technologies has the capacity to produce above 100,000 bbls of lighter oil. The NSolv is based on the downhole injection of alkanes into SAGD well while in the Shell's IUP downhole electric heaters initiate the conversion of heavy oils in subsurface [9]. Even though these methods outside the scope of this paper, being non-catalytic and metal-free, is a lofty beauty to reflect.

In-situ upgrading differs markedly from chemical EOR in that it causes structural changes in the crude, leading to the production of higher quality and recovery factor of the OOIP, and leaving behind coke in the subsurface. In addition, the reservoir mimics a gigantic refining vessel and the production may be carbon-neutral if upgrading is coupled with nuclear or renewable energy generation systems [6]. However, despite these advantages over CEOR, the in-situ upgrading technology is energy-demanding, relatively poorly controllable, has less mixing efficiency, poses more environmental challenge and has limitations on the use of metals [9].

\subsection{Supports in surface upgrading}

The most suitable catalysts for oil upgrading are those containing active sites that can effectively break the $\mathrm{C}-\mathrm{C}, \mathrm{C}-\mathrm{S}, \mathrm{C}-\mathrm{O}, \mathrm{C}-\mathrm{N}$, and other related bonds in resins and asphaltenes [70, 71]. Ultrafine particles of unsupported metals such as base (Mo, W, Ni, V, Co, Cr, Zn etc.) or noble $(\mathrm{Pb}, \mathrm{Rh}, \mathrm{Pt}$, etc.) are good cracking catalysts due to their dispersibility and flow within the heavy oil, and interaction with large molecules. For example, submicronic NiWMo particles can enhance the hydrocracking of heavy oil and inhibit coke production and desulphurisation [72]. However, supports are crucial for 
effective hydrodesulpharisation (HDS), hydrodemetallisation (HDM), hydrodenitrogenation (HDN), and hydroconversion. In fact, ultradispersed, unsupported $\mathrm{NiO}(<$ $50 \mathrm{~nm}), \mathrm{MoO}_{3}(<100 \mathrm{~nm})$, and $\mathrm{Fe}_{2} \mathrm{O}_{3}(50 \mathrm{~nm})$, can improve the viscosity, inhibit coking, and produce better upgraded oil (21 $1^{\circ}$ API, $\left.108 \mathrm{mPa} . \mathrm{s}\right)$ than thermal cracking $\left(24^{\circ}, 53.5\right.$ mPa.s) when operated initially at $450{ }^{\circ} \mathrm{C}, 50$ bar initial $\mathrm{H}_{2}$ pressure for $50 \mathrm{~min}$, then at $425{ }^{\circ} \mathrm{C}$ for $60 \mathrm{~min}$ [73]. This moderate level of upgrade is attributed to the lack of support.

Supported metal catalysts especially the transition metal oxides and sulphides have the capacity to suppress coking and yield high surface conversion of heavy oil and extraheavy oil (37-49\%) [74, 75]. Supports can contribute to the activity or selectivity of the catalysts. Silica or alumina supported Ni and Mo are usually (but not always) good upgrading catalysts [76]. For example, $\mathrm{MgO}$-supported $\mathrm{Ni}$ and $\mathrm{Cu}$ can convert $90 \%$ of mixed acid hydrocarbon solution, but $\mathrm{SiO}_{2}$ and $\mathrm{Al}_{2} \mathrm{O}_{3}$ produced no conversion [77]. The catalysts may perform better in a mix with heated sand than the heated catalyst alone [78] and perform remarkably at lower steam-oil ratio [79], suitable catalyst concentration, acidity, and pore geometry [80]. Certain supported catalysts such as $\mathrm{NiMo} / \mathrm{Al}_{2} \mathrm{O}_{3}$, are highly efficient for the upgrading of pretreated oil [81] while others such as supported haematite, can perform better when applied under supercritical water conditions [82] entailing challenges for large-scale operation.

Zeolites usually are popular active, sulphur-resistant hydrogenation and surface upgrading catalysts but they are susceptible to active site poisoning and coke deposition especially with feedstocks containing residues [83]. Different zeolite catalysts can give a different distribution of upgrade products [84]. In a preliminary study to upgrade Omani heavy oil under microwave heating at $250{ }^{\circ} \mathrm{C}$ and autogenous pressure, combinations of $500 \mu \mathrm{m}, 5 \mathrm{wt} \% \mathrm{NiCoMo}$ on zeolite supports $\left(\mathrm{NH}_{4}\right.$-Zeolite-Y, H-zeolite-Y, $\mathrm{NH}_{4}$-Mordenite, $\mathrm{NH}_{4}$-Zeolite-Y) converted decalin, a model light oil, to several lighter ring-opening products [85]. Commercial ternary and multi-element supported catalysts (such as $\mathrm{MoCoP} /$ $\mathrm{Al}_{2} \mathrm{O}_{3}$ or $\mathrm{MoWNiCoP} / \mathrm{Al}_{2} \mathrm{O}_{3}$ ) have also been outstanding in upgrading heavy oil to useful distillates [86].

To avoid sulphur poisoning noble metals should be used in environments containing below $10 \mathrm{mgS} / \mathrm{g}$ [23]. Generally, Pd stands out among several noble metals for efficiency in hydrocracking (HC) and hydrodesulpharisation (HDS) [87]. Noble metals have also been successful when loaded on natural supports such as clay and metakaolin [75]. In fact, traces of Rh-Pd on high porous saponite containing exchangeable Co exhibit a significant enhancement of the catalytic activity over $\mathrm{Rh}$ alone [88].

\subsection{Hydrogen donors}

Practically, the traditional hydrogen addition and carbon rejection have limitations when used singly in heavy oil surface upgrading [89, 90]. Even though successful upgrading can be performed under an inert atmosphere (He or $\mathrm{N}_{2}$ ), hydrogen donors are crucial to provide the needed $\mathrm{H} / \mathrm{C}$ ratio and avoid coking. In actual fact, heavy crude oil reactivity and hydrogen availability (not catalyst activity), were found to be the primary factors limiting oil upgrading [78]. Basically, the hydrogenation of heavy cuts can be assisted by hydrogen donors such as cyclohexane, sodium borohydride, water, tetralin, ammonia, methanol, ethanol, citric acid, formic acid, hydrazine, methane, pentane, naphtha, and hydrogen [91, 92]. A laboratory-scale in-situ THAI-CAPRI study over alumina catalysts shows a higher potential of methane, ethane, and hydrogen to provide the highest $\mathrm{H} / \mathrm{C}$ ratio and better upgrading [93]. In fact, the partial surface upgrading of bitumen for pipeline transportation with $\mathrm{CH}_{4}$ over the zeolite-supported catalyst at moderate conditions, without diluent addition, has been established [94]. Among fused ring hydrogen donors such as naphthalene, decalin, tetralin, 1-methyl naphthalene, tetralin showed superiority for use in upgrading with $<4 \%$ coke formation [95]. Methane and $\mathrm{Fe}_{3}(\mathrm{CO})_{12}$ assisted HDS and heavy oil conversion efficiencies are equivalent, and are much lower than with $\mathrm{H}_{2}$ [96]. This observation supports a prior evidence which showed no improvement in oil recovery under hydrogen partial pressures below 5.2 $\mathrm{MPa}$ (and $343.3^{\circ} \mathrm{C}$ ) and oil recoveries are higher from experiments carried out under higher $\mathrm{H}_{2}$ partial pressures than under $\mathrm{N}_{2}$ atmosphere [97]. Certain in-situ combustion can generate $\mathrm{CO}$, from which $\mathrm{H}_{2}$ can be produced via water-gas shift, but with implication of coking [98].

\subsection{Modification of heterogeneous catalysts}

The performance of catalysts can be dramatically increased by making key considerations regarding size, catalyst acidity and composition [99]. Carbon-loaded iron and Ni-Mo/ $\mathrm{Al}_{2} \mathrm{O}_{3}$ materials having larger mesopore volume tend to give higher oil conversion and a very high hydrodemetallisation (HDM) and hydrodesulpharisation (HDS) [100]. Similarly, nanoparticles of $\mathrm{NiO}, \mathrm{SiO}_{2}$, and $\mathrm{Fe}_{3} \mathrm{O}_{4}$ can prevent the aggregation of asphaltenes in heptane solutions and increase the adsorption of large molecules [101]. A study with $\mathrm{NiO}$ shows that only certain nano range may be more catalytically effective for upgrading [102].

The surface modification of $\beta$-zeolite catalyst with triphenyl silane has the potential to reduce coke formation and generate $55.7 \% \mathrm{C}_{7}$ to $\mathrm{C}_{13}$ cuts (petrol) from heavy oil in $2 \mathrm{~h}$ [103]. The significant reduction in coke formation 
confirmed the stability of the catalyst. In aquathermolysis, the modification of the surface of heamatite nanoparticles with oleic acid was found to significantly reduce the viscosity and upgrade the quality of heavy crude oil [104]. Similarly, $\mathrm{TiO}_{2}$ has served as a good modifying agent for alumina supporting CoMo, for HDM and HDS [105]. In addition, temperature tolerant ionic liquid-modified catalysts such as imidazolium tetracholoferrate BMIM $\left[\mathrm{FeCl}_{4}\right]$ when added to heavy crude (at $0.25,0.5$ and $1 \%$ catalyst oil ratio) can achieve remarkable reduction in viscosity (52.2\%), and HDS $(20 \%)$ at 70 to $90{ }^{\circ} \mathrm{C}[106]$.

Molybdenum-doped akaganeite ( $c a 30 \mathrm{~nm} \beta$-FeOOH) can form nanorods, which in presence of tetralin exhibit remarkable enhancement in the viscosity reduction rate of extra-heavy crude oil (viscosity $750,000 \mathrm{mPa} . \mathrm{s}$ at $50{ }^{\circ} \mathrm{C}$ ) to $72.7 \%$ [107]. A commonly used catalyst in heavy oil upgrading is the $\mathrm{SO}_{4}{ }^{2-}$-modified $\mathrm{ZrO}_{2}$-based nanoparticle catalyst, but having fewer acid sites and poor hydrothermal stability limited its application [108]. However, modification of the zirconia catalysts by doping or compositing with oxides has proved beneficial. Kondoh et al. [109] found that a fifty-fifty $\mathrm{TiO}_{2}-\mathrm{ZrO}_{2}$ mixed catalyst possesses high BET surface area and acidity compared to either $\mathrm{ZrO}_{2}$ or $\mathrm{TiO}_{2}$, which can improve heavy oil upgrading reactions.

\subsection{Homogeneous catalysts}

The efficacy of homogeneous catalysts to improve oil upgrading. Heavy oil bound sulphur has been removed successfully as sulphide by continuous in-situ process exploiting $\mathrm{NaOH}(10-20 \%)$ at 380 to $450{ }^{\circ} \mathrm{C}$ [110], with the regeneration of the alkali by stripping with in-situ metals. Instead of regeneration, the catalyst can be conveniently removed. A homogenous ammonium molybdate catalyst used in the upgrading was removed by calcining the residue followed by the addition of $\mathrm{NH}_{4} \mathrm{OH}$ and ammonium carbonate and leaching at $60-80{ }^{\circ} \mathrm{C}$ for $1-5 \mathrm{~h} \mathrm{[111]}$.

The acceleration of heavy oil recovery in presence the case of $\mathrm{Fe}\left(\mathrm{CH}_{3} \mathrm{COCHCOCH}_{3}\right)_{3}$ as a homogeneous catalyst is established. A coreflooding study has shown that the addition of $5 \mathrm{wt} \%$ tetralin can increase oil recovery by $15 \%$ while premixing tetralin-catalyst solution with sand mix yielded $20 \%$ higher recovery [112]. Similarly, heavy crude oil can effectively be transformed into lighter oil by a liquid Ni-Mo catalyst from $\left(\mathrm{NH}_{4}\right)_{6} \mathrm{Mo}_{7} \mathrm{O}_{24} \cdot 4 \mathrm{H}_{2} \mathrm{O}$ and $\mathrm{NiSO}_{4} \cdot 6 \mathrm{H}_{2} \mathrm{O}$ [113].

\subsection{Solvent effects and viscosity reduction}

In surface upgrading, the viscosity of the heavy oil may rise due to the absence of hydrogen donors or the presence of oil-insoluble hydrogen donors [91, 114]. Fortunately, the synergistic effect between the catalyst and ultrasonication (a physical process) can reduce up to $86 \%$ of the original viscosity of heavy oil [115]. The synergy between carbon nano-catalysts and microwave heating great viscosity reduction ratio (over $96 \%$ ), short reaction time (less than $1 \mathrm{~h}$ ), and low required temperature (about $150{ }^{\circ} \mathrm{C}$ ) [116]. Nano-nickel catalysts have demonstrated higher ability than iron, Co nanoparticles, and iron(III) oxide to increase the efficiency of microwave heating for viscosity reduction [117, 118]. Under microwave electric heating, in-situ heavy oil recoveries with nano-Ni nanoparticles can rapidly reach high recovery factors (87 \%) [119].

The in-situ upgrading of heavy oil has been studied using different solvents such as supercritical methanol (sc-MeOH) and supercritical water $\left(\mathrm{sc}-\mathrm{H}_{2} \mathrm{O}\right)$ due to their great diffusivity, mass transfer, and the ability to dissolve organic components and gases [119] and a source of hydrogen. In fact, the successful upgrading of bitumen, a semi-solid, in presence of sc- $\mathrm{H}_{2} \mathrm{O}$, to stable lighter components in the presence of a $\mathrm{ZrO}_{2}-\mathrm{Al}_{2} \mathrm{O}_{3}-\mathrm{FeO}_{x}$ catalyst has been reported [120]. The sc- $\mathrm{H}_{2} \mathrm{O}$ is believed to be a source of hydrogen and oxygen which can assist the upgrading process.

\subsection{Downsizing effects}

Nanocatalysts and other nanomaterials have shown superior applicability in in-situ heavy oil upgrading [121, 122] because they eliminate internal and external mass transfer limitations, and contribute to the formation of high gas fractions and high conversion [123]. Ultradispersed metallic nickel nanoparticles can promote hydrogenation and $50 \%$ conversion of asphaltenes and a $70 \%$ reduction in resins, with improved aromatics and saturates fractions [124]. Oxide nano-catalysts such as $\mathrm{NiO}, \mathrm{SiO}_{2}, \mathrm{ZnO}$, $\mathrm{Fe}_{3} \mathrm{O}_{4}, \mathrm{Co}_{3} \mathrm{O}_{4}$ are currently gaining interest [125-128]. Zirconia based nano-catalysts are particularly appealing due to their high acidity and stability in sub- and supercritical water [127] while $\mathrm{ZnO}$ has an unparalleled activity for supercritical water upgrading [128]. Silica-supported iron oxide nano-catalyst is effective in the supercritical water-based hydrogenation of the unsaturated fragments in vacuum residue cracking [129]. Moreover, fumed silica nanoparticles functionalised with $1 \mathrm{wt} \%$ nickel and palladium oxides have shown potentials for use as catalysts in the continuous steam flooding process [130]. The optimisation and integration of oil recovery with in-situ upgrading could be achieved through a Dense Hot Fluid Injection (DHFI) method in which nano-catalyst is injected into the reservoir [131]. Lastly, even though the applicability of supercritical water-oxygen fluid in 
heavy oil conversion has been widely demonstrated, with nanoparticles, the possibility of its use at large scale operation is slim [132]. Similarly, despite the numerous advantages, the use of nanocatalysts in large-scale upgrading application remains a challenge [133].

\subsection{Aquathermolysis}

Aquathermolysis involves metal complex-assisted degradation of large organic molecules in the presence of water as hydrogen donor. When catalyst is applied in the thermal cracking of the heavy oils, it is referred to as catalytic. It is called thermal if the thermal cracking is performed thermal-only, devoid of catalyst. Laboratory and field catalytic aquathermolysis tests have been conducted on various heavy crude oils, especially from China Liaohe fields $[66,134]$. The applicable catalysts are divided into oil-soluble catalysts and water-soluble [135]. An array of transition metal-based oil-soluble catalysts has been reported in the literature $[61,136]$. Instrumental evidence has shown that, during the aquathermolysis, iron(III) tris(acetylacetonate) can form in-situ magnetic nanoparticles (MNPs) which can exhibit synergy with organic solvents to give high conversion of resins into lighter components [137]. With Ni nanoparticles, the recovery of the steam-stimulation technique increased by $22 \%$, while the viscosity of the original oil reduced by $40 \%$ [138].

By the aquathermolysis, resins and asphaltenes can be converted to lighter components on organic acid-derived complexes. For instance, the saturates, aromatics, resins and asphaltenes (SARA) composition of a sand-free Tazhong heavy oil $42.31 \%, 19.70 \%, 13.70 \%, 24.47 \%$ was transformed at $180{ }^{\circ} \mathrm{C}$ for $24 \mathrm{~h}$ by only $0.5 \%$ of this complex to $45.20 \%, 22.74 \%, 1.78 \%$ and $19.28 \%$, respectively, indicating a depolymerisation of resin and asphaltenes to aromatics and saturated hydrocarbons [139]. The viscosity of the Tazhong heavy oil reduced to $920 \mathrm{mPa} . \mathrm{s}$ from 4,080 mPa.s. Some successful aquathermolysis catalysts include Fe(III) complexes of citrate, lactate,

\section{References}

[1] U.S. Energy Information Administration "International Energy Statistics, 2015" [online] Available at: https://www.eia.gov [Accessed: 02 May 2018]

[2] U.S. Energy Information Administration "Annual Energy Outlook 2020 with projections to 2050", [online] Available at: https:// www.eia.gov/outlooks/aeo/pdf/AEO2020\%20Ful1\%20Report.pdf [Accessed: 01 May 2020] and tartrate ligands [140], nano-Keggin heteropoly acid salt, $\mathrm{K}_{3} \mathrm{PMo}_{12} \mathrm{O}_{40}[141]$ and $\left[\left(\mathrm{CH}_{3}\left(\mathrm{CH}_{2}\right)_{3} \mathrm{CH}\left(\mathrm{CH}_{2} \mathrm{CH}_{3}\right)\right.\right.$ $\mathrm{COO}]_{2} \mathrm{Co}$ [142]. Initially, the term "aquathermolysis" was applied to systems consisting of transitional metal ion salts, transitional metal compounds, and some solid superacids which usually form homogeneous phase systems. Nowadays, the term has been extended to heterogeneous systems such as nano-Ni catalyst [143] and oleic acid-modified $\mathrm{NiFe}_{2} \mathrm{O}_{4}$ nanocatalyst [144], which have been successfully used in upgrading.

\section{Conlusion, future directions and challenges}

Various chemical formulations for exploitation in CEOR and thermal EOR have been reviewed. Despite attempts to push the current limits of chemical usage for successful operation, only a few surfactant formulations can be said to work under high salinity $(>200 \mathrm{~g} / \mathrm{L}$ ) and poorly permeable $(5 \mathrm{mD})$ reservoirs [145], hence the thirst for new formulations with integrity under contemporary reservoir conditions. On the other hand, there is a constant need to further study the mechanisms of alkali flooding and mitigate saponification $[125,146]$.

In spite of the proposition of supercritical fluids, future breakthroughs are necessary for their application in field operations. Similarly, works involving nano-materials require serious collaborations to actualize the potential of applying nanotechnology to oil recovery projects to actualize the potential of applying nanotechnology to oil recovery projects, notwithstanding the existing one between academics and oil development companies [147]. Generally, the future of EOR depends on advancements in cost-effective technologies and chemicals.

\section{Acknowledgement}

The author gratefully acknowledges the receipt of important suggestions from the editorial teams of two previous journals which this paper was submitted.

[3] Ding, H., Zhang, N., Zhang, Y., Wei, M., Bai, B. "Experimental Data Analysis of Nanoparticles for Enhanced Oil Recovery", Industrial \& Engineering Chemistry Research, 58(27), pp. 12438-12450, 2019.

https://oi.org/10.1021/acs.iecr.9b02132

[4] Demirbas, A., Bafail, A., Nizami, A. S. "Heavy oil upgrading: Unlocking the future fuel supply", Petroleum Science and Technology, 34(4), pp. 303-308, 2016. https://doi.org/10.1080/10916466.2015.1136949 
[5] Carillo, J. A., Corredor, L. M. "Upgrading of heavy crude oils: Castilla", Fuel Processing Technology, 109, pp. 156-162, 2013. https://doi.org/10.1016/j.fuproc.2012.09.059

[6] Huc, A. Y. "Heavy crude oils. From geology to upgrading. An overview", Technip, Paris, France, 2011.

[7] Gray, M. R. "Upgrading Oilsands Bitumen and Heavy Oil", The University of Alberta Press, Edmonton, AB, Canada, 2015.

[8] Meyer, R. F., Attanasi, E. D. "Heavy Oil and Natural Bitumen - Strategic Petroleum Resources", U.S. Geological Survey Fact Sheet 70-03. [online] Available at: https://pubs.usgs.gov/fs/fs 07003/fs070-03.html\#sidebar [Accessed: 20 November 2020]

[9] Ovalles, C. "Subsurface Upgrading of Heavy Crude Oils and Bitumen", CRC Press, Boca Raton, FL, USA, 2019. https://doi.org/10.1201/9781315181028

[10] Arcelus-Arrillaga, P., Pinilla, J. L., Hellgardt, K., Millan, M. "Application of Water in Hydrothermal Conditions for Upgrading Heavy Oils: A Review", Energy \& Fuels, 31(5), pp. 4571-4587, 2017. https://doi.org/10.1021/acs.energyfuels.7b00291

[11] Ko, K. M., Chon, B.H., Jang, S. B., Jang, H. Y. "Surfactant flooding characteristics of dodecyl alkyl sulfate for enhanced oil recovery", Journal of Industrial and Engineering Chemistry, 20(1), pp. 228-233, 2014.

https://doi.org/10.1016/j.jiec.2013.03.043

[12] Chen, Z., Zhao, X. "Enhancing Heavy-Oil Recovery by Using Middle Carbon Alcohol-Enhanced Waterflooding, Surfactant Flooding, and Foam Flooding", Energy \& Fuels 29(4), pp. 2153-2161, 2015. https://doi.org/10.1021/ef502652a

[13] Nasri, Z., Mozafari, M. "Multivariable statistical analysis and optimization of Iranian heavy crude oil upgrading using microwave technology by response surface methodology (RSM)", Journal of Petroleum Science and Engineering, 161, pp. 427-444, 2018. https://doi.org/10.1016/j.petrol.2017.12.004

[14] Mokheimer, E. M. A., Hamdy, M., Abubakar, Z., Shakeel, M. R., Habeeb, M. A., Mahmoud, M. "A Comprehensive Review of Thermal Enhanced Oil Recovery: Techniques Evaluation", Journal of Energy Resources Technology, 141(3), Article number: 030801, 2019.

https://doi.org/10.1115/1.4041096

[15] Brown, A. R., Hart, A., Coker, V. S., Lloyd, J. R., Wood, J. "Upgrading of heavy oil by dispersed biogenic magnetite catalysts", Fuel, 185, pp. 442-448, 2016. https://doi.org/10.1016/j.fuel.2016.08.015

[16] Donaldson, E. C., Chilingarian, G. V., Yen, T. F. "Enhanced oil recovery, II: Processes and Operations", Elsevier Science Publishers B.V.s, Amsterdam, Netherlands, 1989.

[17] Ahmadi, M. A., Zendehboudi, S., Shahfiei, A., James, L. "Nonionic Surfactant for Enhanced Oil Recovery from Carbonates: Adsorption Kinetics and Equilibrium", Industrial \& Engineering Chemistry Research, 51(29), pp. 9894-9905, 2012. https://doi.org/10.1021/ie300269c

[18] Liyanage, P. J., Lu, J., Arachchilage, G. W. P., Weerasooriya, U. P., Pope, G. A. "A novel class of large-hydrophobe tristyrylphenol (TSP) alkoxy sulfate surfactants for chemical enhanced oil recovery", Journal of Petroleum Science and Engineering ,128, pp. 73-85, 2015.

https://doi.org/10.1016/j.petrol.2015.02.023
[19] Negin, C., Ali, S., Xie, Q. "Most common surfactants employed in chemical enhanced oil recovery", Petroleum, 3(2), pp. 197-211, 2017. https://doi.org/10.1016/j.petlm.2016.11.007

[20] Chou, S., Capmpbell, C. "Oil recovery for waxy crude oil using alkylaryl sulfonate surfactants derived from alpha-olefins and the alpha-olefin compositions", San Ramon, CA, USA, WO 00/37775, 2000.

[21] Sun, Q., Li, Z., Li, S., Jiang, L., Wang, J., Wang, P. "Utilization of Surfactant-Stabilized Foam for Enhanced Oil Recovery by Adding Nanoparticles", Energy \& Fuels, 28(4), pp. 2384-2394, 2014. https://doi.org/10.1021/ef402453b

[22] Iglauer, S., Wu, Y., Shuler, P., Tang, Y., Goddard, W. A. "New surfactant classes for enhanced oil recovery and their tertiary oil recovery potential", Journal of Petroleum Science \& Engineering, 71(1-2), pp. 23-29, 2010. https://doi.org/10.1016/j.petrol.2009.12.009

[23] Chen, J., De Crisci, A. G., Xing, T. "Review on catalysis related research at CanmetENERGY", The Canadian Journal of Chemical Engineering, 94(1), pp. 7-19, 2016. https://doi.org/10.1002/cjee.22322

[24] Guo, K., Li, H., Yu, Z. "In-situ heavy and extra-heavy oil recovery: A review", Fuel, 185, pp. 886-902, 2016. https://doi.org/10.1016/j.fuel.2016.08.047

[25] Bezagouta, M. S., AlNashef, I. M., Karnanda, W., Al-Khidir, K. "Ionic liquids as novel surfactants for potential use in enhanced oil recovery", Korean Journal of Chemical Engineering, 30(11), pp. 2108-2117, 2013. https://doi.org/10.1007/s11814-013-0137-1

[26] Thomas, S., Ali, S. M. F. "Status and Assessment of Chemical Oil Recovery Methods", Energy Sources, 21(1-2), pp. 177-189, 1999. https://doi.org/10.1080/00908319950015046

[27] Ahmadi, M. A., Shadizadeh, S. R. "Implementation of a high-performance surfactant for enhanced oil recovery from carbonate reservoirs", Journal of Petroleum Science and Engineering, 110, pp. 66-73, 2013. https://doi.org/10.1016/j.petrol.2013.07.007

[28] Delamaide, E., Zaitoun, A., Renard, G., Tabarry, R. "Pelican Lake Field: First Successful Application of Polymer Flooding in a Heavy Oil Reservoir", presented at SPE Enhanced Oil Recovery Conference, Kuala Lumpur, Malaysia, July 022013. https://doi.org/10.2118/165234-MS

[29] Sheng, J. J., Leonhardt, B., Azri, N. "Status of Polymer-Flooding Technology", Journal of Canadian Petroleum Technology, 54(2), pp. 116-126, 2015. https://doi.org/10.2118/174541-PA

[30] Gao, C. H. "Advances of Polymer Flood in Heavy Oil Recovery", In: SPE Heavy Oil Conference and Exhibition, Kuwait City, Kuwait, 2011, Article number: SPE-150384-MS. https://doi.org/10.2118/150384-MS

[31] Abidin, A. Z., Puspasari, T., Nugroho, W. A. "Polymers for Enhanced Oil Recovery Technology", Procedia Chemistry, 4, pp. 11-16, 2012. https://doi.org/10.1016/j.proche.2012.06.002

[32] Wever, D. A. Z., Picchioni, F., Broekhuis, A. A. "Comblike Polyacrylamides as Flooding Agent in Enhanced Oil Recovery", Industrial \& Engineering Chemistry Research 52(46), pp. 16352-16363, 2013. https://doi.org/10.1021/ie402526k 
[33] Zhong, C., Luo, P., Ye, Z., Chen, H. "Characterization and Solution Properties of a Novel Water-soluble Terpolymer For Enhanced Oil Recovery", Polymer Bulletin 62(1), pp. 79-89, 2009. https://doi.org/10.1007/s00289-008-1007-6

[34] Li, J., Liu, Y., Wang, Q., Han, Y., Wang, M., Tan, Y. "Heavy Oil Viscosity Reduction Performance of Novel Water-Soluble Terpolymers", Energy \& Fuels, 33(10), pp. 9736-9746, 2019. https://doi.org/10.1021/acs.energyfuels.9b02425

[35] Gao, C., Shi, J., Zhao, F. "Successful polymer flooding and surfactant-polymer flooding projects at Shengli Oilfield from 1992 to 2012", Journal of Petroleum Exploration and Production Technology, 4(1), pp. 1-8, 2013. https://doi.org/10.1007/s13202-013-0069-7

[36] Liu, Z., Li, Y., Leng, R., Liu, Z., Chen, X., Hejazi, H. "Effects of pore structure on surfactant/polymer flooding-based enhanced oil recovery in conglomerate reservoirs", Petroleum Exploration and Development, 47(1), pp. 134-145, 2020. https://doi.org/10.1016/S1876-3804(20)60012-X

[37] Guo, K., Zhang, Y., Shi, Q., Yu, Z. "Toward understanding the anticorrosive mechanism of some thiourea derivatives for carbon steel corrosion: A combined DFT and molecular dynamics Investigation", Energy \& Fuels, 31, pp. 6045-6055, 2017. https://doi.org/10.1021/acs.energyfuels.7b00809

[38] Song, B., Hu, X., Shui, X., Cui, Z., Wang, Z. "A new type of renewable surfactants for enhanced oil recovery: Dialkylpolyoxyethylene ether methyl carboxyl betaines", Colloids and Surfaces A: Physicochemical and Engineering Aspects, 489, pp. 433-440, 2016. https://doi.org/10.1016/j.colsurfa.2015.11.018

[39] Zhu, Y., Zhang, Y., Niu, J., Liu, W., Hou, Q. "The research progress in the alkali-free surfactant-polymer combination flooding technique", Petroleum Exploration and Development, 39(3) pp. 371-376, 2012. https://doi.org/10.1016/S1876-3804(12)60053-6

[40] Fu, L., Zhang, G., Ge, J., Liao, K., Pei, H., Jiang, P., Li, X. "Study on organic alkali-surfactant-polymer flooding for enhanced ordinary heavy oil recovery", Colloids and Surfaces A: Physicochemical and Engineering Aspects, 508, pp. 230-239, 2016.

https://doi.org/10.1016/j.colsurfa.2016.08.042

[41] Bai, Y., Xiong, C., Shang, X., Xin, Y. "Experimental Study on Ethanolamine/Surfactant Flooding for Enhanced Oil Recovery", Energy \& Fuels, 28(3), pp. 1829-1837, 2014. https://doi.org/10.1021/ef402313n

[42] Bera, A., Mandal, A., Guha, B. B. "Synergistic Effect of Surfactant and Salt Mixture on Interfacial Tension Reduction between Crude Oil and Water in Enhanced Oil Recovery", Journal of Chemical \& Engineering Data, 59(1), pp. 89-96, 2014. https://doi.org/10.1021/je400850c

[43] Afekare, D., Gupta, I., Rao, D. "Nanoscale investigation of silicon dioxide nanofluids and implications for enhanced oil recovery An atomic force microscope study", Journal of Petroleum Science and Engineering, 191, Article number: 107165, 2020. https://doi.org/10.1016/j.petrol.2020.107165

[44] Lu, J., Goudarzi, A., Chen, P., Kim, D. H., Delshad, M., Mohanty, K. K., Sepehrnoori, K., Weerasooriya, U. P., Pope, G. A. "Enhanced oil recovery from high-temperature, high-salinity naturally fractured carbonate reservoirs by surfactant flood", Journal of Petroleum Science and Engineering, 124, pp. 122-131, 2014. https://doi.org/10.1016/j.petrol.2014.10.016
[45] Alvarado, V., Manrique, E. "Enhanced Oil Recovery: An Update Review", Energies, 3(9), pp. 1529-1575, 2010. https://doi.org/10.3390/en3091529

[46] El-hoshoudy, A. N., Desouky, S. E. M., Al-sabagh, A. M., Betiha, M. A., El-kady, M. Y., Mahmoud, S. "Evaluation of solution and rheological properties for hydrophobically associated polyacrylamide copolymer as a promised enhanced oil recovery candidate", Egyptian Journal of Petroleum, 26(3), pp. 779-785, 2017. https://doi.org/10.1016/j.ejpe.2016.10.012

[47] Dahbag, M. B., Mohammadi, M., Khalifi, M., Aghajamali, M., Zirrahi, M., Hassanzadeh, H. "Efficiency of Urea Solutions in Enhanced Oil Recovery", ACS Omega, 5(11), pp. 6122-6129, 2020. https://doi.org/10.1021/acsomega.0c00117

[48] Scott, A. J., Penlidis, A. "Designing Optimal Terpolymers for Enhanced Oil Recovery (Polymer Flooding)", Industrial \& Engineering Chemistry Research, 59(16), pp. 7426-7437, 2020. https://oi.org/10.1021/acs.iecr.0c00434

[49] Han, P., Geng, J., Ding, H., Zhang, Y., Bai, B. "Experimental study on the synergistic effect of nanogel and low salinity water on enhanced oil recovery for carbonate reservoirs", Fuel, 265, Article number: 116971, 2020. https://doi.org/10.1016/j.fuel.2019.116971

[50] Ramos, G.A.R., Akanji, L.T., Afzal, W. "A Novel SurfactantPolymer/Alkaline-Surfactant-Polymer Formulation for Enhanced Oil Recovery (EOR) Processes", Energy \& Fuels, 34(2), pp. 1230-1239, 2020. https://doi.org/10.1021/acs.energyfuels.9b02275

[51] El-hoshoudy, A. N., Hosny, R., Fathy, M., Abdelraheem, O. H., Gomaa, S., Desouky, S. M. "Enhanced oil recovery using polyacrylates/ACTF crosslinked composite: Preparation, characterization and coreflood investigation", Journal of Petroleum Science and Engineering, 181, Article number: 106236, 2019. https://doi.org/10.1016/j.petrol.2019.106236

[52] Li, Y., Puerto, M., Bao, X., Zhang, W., Jin, J., Su, Z., Shen, S., Hirasaki, G., Miller, C. "Synergism and Performance for Systems Containing Binary Mixtures of Anionic/Cationic Surfactants for Enhanced Oil Recovery", Journal of Surfactants and Detergents, 20(1), pp. 21-34, 2017. https://doi.org/10.1007/s11743-016-1892-x

[53] Sagala, F., Hethnawi, A., Nassar, N. N. "Hydroxyl-functionalized silicate-based nanofluids for enhanced oil recovery", Fuel, 269, Article number: 117462, 2020. https://doi.org/10.1016/j.fuel.2020.117462

[54] Kurnia, I., Zhang, G., Han, X., Yu, J. "Zwitterionic-anionic surfactant mixture for chemical enhanced oil recovery without alkali", Fuel, 259, Article number: 116236, 2020. https://doi.org/10.1016/j.fuel.2019.116236

[55] Morvan, M., Moreau, P., Tabary, R., Bazin, B. "Ethoxylated desorbing agents for enhanced oil recovery", IFP Energies Nouvelles, Rhodia Operations, Rueil-Malmaison, France, WO/2016/202975, 2016.

[56] Cui, L., Bourrel, M., Dubos, F., Klimenko, A., Total, S. E. "Surfactant for enhanced oil recovery", US Patent Application Publication, US20200010756 A1, 2020.

[57] Quintero, Q., Koh, H., Baker Hughes Inc "Formulation to increase oil recovery", USA, US20200010757 A1, 2020. 
[58] Wu, Y., Chen, W., Dai, C., Huang, Y., Li, H., Zhao, M., He, L., Jiao, B. "Reducing surfactant adsorption on rock by silica nanoparticles for enhanced oil recovery", Journal of Petroleum Science and Engineering, 153, pp. 283-287, 2017. https://doi.org/10.1016/j.petrol.2017.04.015

[59] Wu, H., Gao, K., Lu, Y., Meng, Z., Gou, C., Li, Z., Yang, M., Qu, M., Liu, T., Hou, J., Kang, W. "Silica-based amphiphilic Janus nanofluid with improved interfacial properties for enhanced oil recovery", Colloids and Surfaces A: Physicochemical and Engineering Aspects, 586, Article number: 124162, 2020. https://doi.org/10.1016/j.colsurfa.2019.124162

[60] Demirbas, A., Alsulami, H. E., Hassanein, W. S. "Utilization of Surfactant Flooding Processes for Enhanced Oil Recovery (EOR)", Petroleum Science and Technology, 33(12), pp. 1331-1339, 2015. https://doi.org/10.1080/10916466.2015.1060503

[61] Jia, H., Liu, P. G., Pu, W. F., Ma, X. P., Zhang, J., Gan, L. "In situ catalytic upgrading of heavy crude oil through low-temperature oxidation", Petroleum Science, 13(3), pp. 476-488, 2016. https://doi.org/10.1007/s12182-016-0113-6

[62] Speight, J.G. "Enhanced Recovery Methods for Heavy Oil and Tar Sands", Gulf Publishing Company, Houston, Texas, 2009. https://doi.org/10.1016/C2013-0-15525-0

[63] Dim, P., Hart, A., Wood, J., Macnaughtan, B., Rigby, S. P. "Characterization of pore coking in catalyst for thermal downhole upgrading of heavy oil", Chemical Engineering Science, 131, pp. 138-145, 2015. https://doi.org/10.1016/j.ces.2015.03.052

[64] Greaves, M., Xia, T. X. "Downhole upgrading of Wolf Lake oil using THAI/CAPRI processes - tracer tests", Preprints of Symposia - American Chemical Society, 49(1), pp. 69-72, 2004.

[65] Davudov, D., Moghanloo, R. G. "A systematic comparison of various upgrading techniques for heavy oil", Journal of Petroleum Science and Engineering, 156, pp. 623-632, 2017. https://doi.org/10.1016/j.petrol.2017.06.040

[66] Ramirez-Corredores, M. M. "The Science and Technology of Unconventional Oils: Finding Refining Opportunities", Academic Press, Cambridge, MA, USA, 2017.

[67] Castañeda, L. C., Muñoz, J. A. D., Ancheyta, J. "Current situation of emerging technologies for upgrading of heavy oils", Catalysis Today, 220-222, pp. 248-273, 2014. https://doi.org/10.1016/j.cattod.2013.05.016

[68] Demirbas, A., Al-Ghamdi, K., Sen, N., Aslan, A., Alalayah, W. M. "Gasoline- and diesel-like products from heavy oils via catalytic pyrolysis", Petroleum Science and Technology, 35(15), pp. 1607-1613, 2017. https://doi.org/10.1080/10916466.2017.1336768

[69] Hart, A. "The novel THAI-CAPRI technology and its comparison to other thermal methods for heavy oil recovery and upgrading", Journal of Petroleum Exploration and Production Technology, 4(4), pp. 427-437, 2014. https://doi.org/10.1007/s13202-013-0096-4

[70] Petrukhina, N. N., Kayukova, G. P., Romanov, G. V., Tumanyan, B. P., Foss, L. E., Kosachev, I. P., Musin, R. Z., Ramazanova, A. I, Vakhin, A. V. "Conversion Processes for High-Viscosity Heavy Crude Oil in Catalytic and Noncatalytic Aquathermolysis", Chemistry and Technology of Fuels and Oils, 50(4), pp. 315-326, 2014. https://doi.org/10.1007/s10553-014-0528-y
[71] Tang, X. D., Chen, X. D., Li, J. J., Deng, L. Y., Liang, G. J. "Experimental Study on Homogeneous Catalytic Upgrading of Heavy Oil", Petroleum Chemistry 57(12), pp. 1018-1023, 2017. https://doi.org/10.1134/S0965544117120143

[72] Galarraga, C. E., Pereira-Almao, P. "Hydrocracking of Athabasca Bitumen Using Submicronic Multimetallic Catalysts at Near In-Reservoir Conditions", Energy \& Fuels, 24(4), pp. 2383-2389, 2010.

https://doi.org/10.1021/ef9013407

[73] Al-marshed, A., Hart, A., Leeke, G., Greaves, M., Wood, J. "Effectiveness of Different Transition Metal Dispersed Catalysts for In-Situ Heavy Oil Upgrading", Industrial \& Engineering Chemistry Research, 54(43), pp. 10645-10655, 2015. https://doi.org/10.1021/acs.iecr.5b02953

[74] Quitian, A., Ancheyta, J. "Partial Upgrading of Heavy Crude Oil by Slurry-Phase Hydrocracking with Analytical Grade and Ore Catalysts", Energy \& Fuels, 30(12), pp. 10117-10125, 2016. https://doi.org/10.1021/acs.energyfuels.6b01648

[75] López, D., Giraldo, L. J., Salazar, J. P., Zapata, D. M., Ortega, D. C., Franco, C. A., Cortés, F. B. "Metal Oxide Nanoparticles Supported on Macro-Mesoporous Aluminosilicates for Catalytic Steam Gasification of Heavy Oil Fractions for On-Site Upgrading", Catalysts, 7(11), Article number: 319, 2017. https://doi.org/10.3390/catal7110319

[76] Reina, T. R., Yeletsky, P., Bermúdez, J. M., Arcelus-Arrillaga, P., Yakovlev, V. A., Millan, M. "Anthracene aquacracking using $\mathrm{NiMo} / \mathrm{SiO}_{2}$ catalysts in supercritical water conditions", Fuel, 182, pp. 740-748, 2016. https://doi.org/10.1016/j.fuel.2016.06.038

[77] Zhang, A., Ma, Q., Wang, K., Liu, X., Shuler, P., Tang, Y. "Naphthenic acid removal from crude oil through catalytic decarboxylation on magnesium oxide", Applied Catalysis A: General, 303(1), pp. 103-109, 2006. https://doi.org/10.1016/j.apcata.2006.01.038

[78] Weissman, J. G., Kessler, R. V., Sawicki, R. A. "Down-Hole Catalytic Upgrading of Heavy Crude Oil", Energy \& Fuels, 10(4), pp. 883-889, 1996. https://doi.org/10.1021/ef9501814

[79] Hart, A., Leeke, G., Greaves, M., Wood, J. "Downhole Heavy Crude Oil Upgrading Using CAPRI: Effect of Steam upon Upgrading and Coke Formation", Energy \& Fuels, 28(3), pp. 1811-1819, 2014. https://doi.org/10.1021/ef402300k

[80] Minja, R. J. A., Ternan, M. "Effect of H-mordenite zeolite as a component in Co-Mo- $\mathrm{Al}_{2} \mathrm{O}_{3}$ hydroprocessing catalysts used for the conversion of Boscan heavy oil", Fuel, 70(1), pp. 44-50, 1991. https://doi.org/10.1016/0016-2361(91)90093-P

[81] Díaz-Boffelli, G., Ancheyta, J., Muñoz, J. A. D., Centeno, G. "Experimental Study and Economic Analysis of Heavy Oil Partial Upgrading by Solvent Deasphalting-Hydrotreating", Energy \& Fuels, 32(1), pp. 55-59, 2018. https://doi.org/10.1021/acs.energyfuels.7b02442

[82] Hosseinpour, M., Ahmadi, S. J., Fatemi, S. "Successive co-operation of supercritical water and silica-supportediron oxide nanoparticles in upgrading of heavy petroleum residue: Suppression of coke deposition over catalyst", Journal of Supercritical Fluids, 100, pp. 70-78, 2015.

https://doi.org/10.1016/j.supflu.2015.02.013 
[83] Sato, K., Iwata, Y., Miki, Y., Shimada, H. "Hydrocracking of Tetralin over NiW/USY Zeolite Datalysts: For the Improvement of Heavy-Oil Upgrading Catalysts", Journal of Catalysis 186(1), pp. 45-56, 1999. https://doi.org/10.1006/jcat.1999.2546

[84] Xiong, K., Lu, C., Wang, Z., Gao, X. "Kinetic study of catalytic cracking of heavy oil over an in-situ crystallized FCC catalyst", Fuel, 142, pp. 65-72, 2015.

https://doi.org/10.1016/j.fuel.2014.10.072

[85] Gaya, U. I., Jibril, B. Y., Al-Wehaibi, Y. M., Al-Hajri, R. S., Naser, J. T. "Ring Opening of Decalin over Zeolite-Supported Ni-Co-Mo Catalysts", In: 2012 International Conference on Environment, Chemistry and Biology, Hong Kong, China, 2012, pp. 139-143. [online] Available at: http://www.ipcbee.com/ vo149/028-ICECB2012-E1003.pdf [Accessed: 30 July 2020]

[86] Nares, H. R., Schacht-Hernández, P., Cabrera-Reyes, M. C., Ramírez-Garnica, M., Cazarez-Candia, O. "Upgrading of Heavy Crude Oil with Supported and Unsupported Transition Metals", In: Canadian International Petroleum Conference, Calgary, AB, Canada, 2006.

https://doi.org/10.2118/2006-060

[87] Hossain, M. M. "Co-Pd/-A12O3 catalyst for heavy oil upgrading: Desorption kinetics, reducibility and catalytic activity", The Canadian Journal of Chemical Engineering, 90(4), pp. 946-955, 2012.

https://doi.org/10.1002/cjce.20595

[88] Hossain, M. M., Al-Saleh, M. A., Shalabi, M. A., Kimura, T., Inui, T. "Pd-Rh promoted Co/HPS catalysts for heavy oil upgrading", Applied Catalysis A: General, 278(1), pp. 65-71, 2004. https://doi.org/10.1016/j.apcata.2004.09.026

[89] Yan, T., Xu, J., Wang, L., Liu, Y., Yang, C., Fang, T. "A review of upgrading heavy oils with supercritical fluids", RSC Advances, 5, pp. 75129-75140, 2015.

https://doi.org/10.1039/c5ra08299d

[90] Zhang, Y., Huang, L., Xi, X., Li, W., Sun, G., Gao, S., Zhang, S. "Deep Conversion of Venezuela Heavy Oil via Integrated Cracking and Coke Gasification-Combustion Process", Energy \& Fuels, 31(9), pp. 9915-9922, 2017.

https://doi.org/10.1021/acs.energyfuels.7b01606

[91] Askarian, M., Vatani, A., Edalat, M. "Heavy oil upgrading via hydrodynamic cavitation in the presence of an appropriate hydrogen donor", Journal of Petroleum Science and Engineering, 151, pp. 55-61, 2017. https://doi.org/10.1016/j.petrol.2017.01.037

[92] Hart, A., Lewis, C., White, T., Greaves, M., Wood, J. "Effect of cyclohexane as hydrogen-donor in ultradispersed catalytic upgrading of heavy oil", Fuel Processing Technology, 138, pp. 724-733, 2015.

https://doi.org/10.1016/j.fuproc.2015.07.016

[93] Hart, A., Wood, J., Greaves, M. "Laboratory investigation of CAPRI catalytic THAI-add-on process for heavy oil production and in situ upgrading", Journal of Analytical and Applied Pyrolysis, 128, pp. 18-26, 2017.

https://doi.org/10.1016/j.jaap.2017.11.004
[94] Guo, A., Wu, C., He, P., Luan, Y., Zhao, L., Shan, W., Cheng, W., Song, H. "Low-temperature and low-pressure non-oxidative activation of methane for upgrading heavy oil", Catalysis Science \& Technology, 6(4), pp. 1201-1213, 2016. https://doi.org/10.1039/C5CY00947B

[95] Kim, S. H., Kim, K. D., Lee, H., Lee, Y. K. "Beneficial roles of $\mathrm{H}$-donors as diluent and $\mathrm{H}$-shuttle for asphaltenes in catalytic upgrading of vacuum residue", Chemical Engineering Journal, 314, pp. 1-10, 2017. https://doi.org/10.1016/j.cej.2016.12.119

[96] Ovalles, C., Rivero, V., Salazar, A. "Downhole Upgrading of Orinoco Basin Extra-Heavy Crude Oil Using Hydrogen Donors under Steam Injection Conditions. Effect of the Presence of Iron Nanocatalysts", Catalysts, 5(1), pp. 286-297, 2015. https://doi.org/10.3390/catal5010286

[97] Stapp, P. R. "In situ hydrogenation", US Department of Energy, Assistant Secretary for Fossil Energy, Bartlesville, OK, USA, Rep. NIPER-434, 1989. https://doi.org/10.2172/5239585

[98] Gates, I. D., Chakrabarty, N., Moore, R. G., Mehta, S. A., Zalewski, E., Pereira, P. "In Situ Upgrading of Llancanelo Heavy Oil Using In Situ Combustion and a Downhole Catalyst Bed", Journal of Canadian Petroleum Technology, 47(9), Article number: PETSOC-08-09-23, 2008.

https://doi.org/10.2118/08-09-23

[99] Inamura, K., Kagami, N., Shirakawa, T., Eura, S., Watabe, M. "Improvement in hydrocracking activity of heavy oil upgrading catalyst by modifications to some specific properties of Y-zeolite", Research on Chemical Intermediates, 41(12), pp. 9451-9461, 2015. https://doi.org/10.1007/s11164-015-1970-0

[100] Fukuyama, H., Terai, S., Uchida, M., Cano, J. L., Ancheyta, J. "Active carbon catalyst for heavy oil upgrading", Catalysis Today 98(1-2), pp. 207-215, 2004. https://doi.org/10.1016/j.cattod.2004.07.054

[101] Kazemzadeh, Y., Eshraghi, S. E., Kazemi, K., Sourani, S., Mehrabi, M., Ahmadi, Y. "Behavior of Asphaltene Adsorption onto the Metal Oxide Nanoparticles Surface and Its Effect on Heavy Oil Recovery", Industrial \& Engineering Chemistry Research, 54(1), pp. 233-239, 2015. https://doi.org/10.1021/ie503797g

[102] Marei, N. N., Nassar, N. N., Vitale, G., Hassan, A., Zurita, M. J. P. "Effects of the size of $\mathrm{NiO}$ nanoparticles on the catalytic oxidation of Quinolin-65 as an asphaltene model compound", Fuel, 207, pp. 423-437, 2017. https://doi.org/10.1016/j.fuel.2017.06.106

[103] Khalil, U., Muraza, O., Kondoh, H., Watanabe, G., Nakasaka, Y., Al-Amer, A., Masuda, T. "Robust surface-modified Beta zeolite for selective production of lighter fuels by steam-assisted catalytic cracking from heavy oil", Fuel 168, pp. 61-67, 2016. https://doi.org/10.1016/j.fuel.2015.11.085

[104] Khalil, M., Liu, N., Lee, R. L. "Catalytic Aquathermolysis of Heavy Crude Oil Using Surface-Modified Hematite Nanoparticles", Industrial \& Engineering Chemistry Research, 56(15), pp. 4572-4579, 2017.

https://doi.org/10.1021/acs.iecr.7b00468 
[105] Rana, M. S., Ancheyta, J., Maity, S. K., Rayo, P. "Maya crude hydrodemetallization and hydrodesulfurization catalysts: An effect of $\mathrm{TiO}_{2}$ incorporation in $\mathrm{Al}_{2} \mathrm{O}_{3}$ ", Catalysis Today, 109(1-4), pp. 61-68, 2005 .

https://doi.org/10.1016/j.cattod.2005.08.016

[106] Shaban, S., Dessouky, S., Badawi, A. F., Sabagh, A., Zahran, A., Mousa, M. "Upgrading and Viscosity Reduction of Heavy Oil by Catalytic Ionic Liquid", Energy \& Fuels, 28(10), pp. 6545-6553, 2014. https://doi.org/10.1021/ef500993d

[107] Zhao, K., Wang, X., Pan, H., Li, Q., Yang, J., Li, X., Zhang, Z. "Preparation of molybdenum-doped akaganeite nano-rods and their catalytic effect on the viscosity reduction of extra heavy crude oil", Applied Surface Science, 427, pp. 1080-1089, 2018. https://doi.org/10.1016/j.apsusc.2017.09.097

[108] Su, L., Guan, Z., Li, Q., Li, C., Wang, X., Li, X., Yang, J., Zhang, Z. "Synthesis of SO4 2-/Zr-silicalite-1 zeolite catalysts for upgrading and visbreaking of heavy oil", Journal of Nanoparticle Research, 19(9), Article number: 305, 2017. https://doi.org/10.1007/s11051-017-4002-8

[109] Kondoh, H., Tanaka, K., Nakasaka, Y., Tago, T., Masuda, T. "Catalytic cracking of heavy oil over $\mathrm{TiO}_{2}-\mathrm{ZrO}_{2}$ catalysts under superheated steam conditions", Fuel, 167, pp. 288-294, 2016. https://doi.org/10.1016/j.fuel.2015.11.075

[110] Brons, G., Myers, R. D. "Continuous in-situ process for upgrading heavy oil using aqueous base", 5,635,056, 1995.

[111] Masoudian, S. K., Sadighi, S. "Recovering ammonium molybdate catalyst in the homogenous phase to upgrade heavy crude oil", Petroleum \& Coal, 58(4), pp. 461-464, 2016. [online] Available at: https://www.vurup.sk/na_stiahnutie/recovering-ammonium-molybdate-catalyst-homogenous-phase-upgrade-heavy-crude-oil/ [Accessed: 30 July 2020]

[112] Mohammad, A. A. A., Mamora, D. D. "Insitu Upgrading of Heavy Oil Under Steam Injection With Tetralin and Catalyst", In: International Thermal Operations and Heavy Oil Symposium, Calgary, AB, Canada, 2008, Article number: SPE-117604-MS. https://doi.org/10.2118/117604-MS

[113] García, F. J. O., Juárez, E. M. "Heavy Oil Hydrocracking on a Liquid Catalyst", Energy \& Fuels, 31(8), pp. 7995-8000, 2017. https://doi.org/10.1021/acs.energyfuels.7b01132

[114] Askarian, M., Vatani, A., Edalat, M. "Heavy oil upgrading in a hydrodynamic cavitation system: CFD modelling, effect of the presence of hydrogen donor and metal nanoparticles", The Canadian Journal of Chemical Engineering, 95(4), pp. 670-679, 2017. https://doi.org/10.1002/cjce.22709

[115] Xu, H. X., Pu, C. S. "Experimental study of heavy oil underground aquathermolysis using catalyst and ultrasonic", Journal of Fuel Chemistry and Technology, 39(8), pp. 606-610, 2011. https://doi.org/10.1016/S1872-5813(11)60037-6

[116] Li, K., Hou, B., Wang, L., Cui, Y. "Application of Carbon Nanocatalysts in Upgrading Heavy Crude Oil Assisted with Microwave Heating", Nano Letters, 14(6), pp. 3002-3008, 2014. https://doi.org/10.1021/n1500484d

[117] Greff, J., Babadagli, T. "Use of nano-metal particles as catalyst under electromagnetic heating for in-situ heavy oil recovery", Journal of Petroleum Science and Engineering, 112, pp. 258-265, 2013. https://doi.org/10.1016/j.petrol.2013.11.012
[118] Guo, K., Hansen, V. F., Li, H., Yu, Z. "Monodispersed nickel and cobalt nanoparticles in desulfurization of thiophene for in-situ upgrading of heavy crude oil", Fuel, 211, pp. 697-703, 2018. https://doi.org/10.1016/j.fuel.2017.09.097

[119] Yan, T., Chen, K., Wang, L., Liu, Y., Zhang, Y., Jiang, Z., Fang, T. "Experimental Investigation of Upgrading Heavy Oil with Supercritical Methanol", Energy \& Fuels, 31(6), pp. 5882-5890, 2017.

https://doi.org/10.1021/acs.energyfuels.7b00355

[120] Hossain, M. M. "Upgrading of Heavy Oil in Supercritical Water using an Iron based Multicomponent Catalyst", International Journal of Chemical Rector Engineering, 15(1), pp. 161-167, 2017. https://doi.org/10.1515/ijcre-2016-0169

[121] Alaei, M., Bazmi, M., Rashidi, A., Rahimi, A. "Heavy crude oil upgrading using homogenous nanocatalyst", Journal of Petroleum Science and Engineering, 158, pp. 47-55, 2017. https://doi.org/10.1016/j.petrol.2017.08.031

[122] Cardona, L., Arias-Madrid, D., Cortés, F. B., Lopera, S. H., Franco, C. A. "Heavy Oil Upgrading and Enhanced Recovery in a Steam Injection Process Assisted by NiO- and PdOFunctionalized $\mathrm{SiO}_{2}$ Nanoparticulated Catalysts", Catalysts, 8(4), Article number: 132, 2018. https://doi.org/10.3390/catal8040132

[123] Eshraghian, A., Husein, M. M. "Catalytic thermal cracking of Athabasca VR in a closed reactor system", Fuel, 217, pp. 409-419, 2018. https://doi.org/10.1016/j.fuel.2017.12.115

[124] Alkhaldi, S., Husein, M. M. "Hydrocracking of Heavy Oil by Means of In Situ Prepared Ultradispersed Nickel Nanocatalyst", Energy \& Fuels, 28(1), pp. 643-649, 2014. https://doi.org/10.1021/ef401751s

[125] Park, C., Jung, J., Lee, C. W. "Synthesis of Mesoporous $\alpha$-Fe2O3 Nanoparticles by Non-ionic Soft Template and Their Applications to Heavy Oil Upgrading", Scientific Reports, 6(1), Article number: 39136, 2016.

https://doi.org/10.1038/srep39136

[126] Kosari, M., Golmohammadi, M., Ahmadi, S. J., Towfighi, J., Chenari, H. "On the catalysis capability of transition metal oxide nanoparticles in upgrading of heavy petroleum residue by supercritical water", The Journal of Supercritical Fluids, 126, pp. 14-24, 2017.

https://doi.org/10.1016/j.supflu.2017.02.021

[127] Kang, J., Myint, A. A., Sim, S., Kim, J., Kong, W. B., Lee, Y.-W. "Kinetics of the upgrading of heavy oil in supercritical methanol", The Journal of Supercritical Fluids, 133(1), pp. 133-138, 2018. https://doi.org/10.1016/j.supflu.2017.10.005

[128] Masudi, A., Muraza, O. "Zirconia-Based Nanocatalysts in Heavy Oil Upgrading: A Mini Review", Energy \& Fuels, 32(3), pp. 2840-2854, 2018. https://doi.org/10.1021/acs.energyfuels.7b03264

[129] Timko, M. T., Ghoniem, A. F., Green, W. H. "Upgrading and desulfurization of heavy oils by supercritical water", The Journal of Supercritical Fluids, 96, pp. 114-123, 2015. https://doi.org/10.1016/j.supflu.2014.09.015 
[130] Hosseinpour, M., Fatemi, S., Ahmadi, S. J. "Deuterium tracing study of unsaturated aliphatics hydrogenation by supercritical water in upgrading heavy oil. Part II: Hydrogen donating capacity of water in the presence of iron(III) oxide nanocatalyst", The Journal of Supercritical Fluids, 110, pp. 75-82, 2016. https://doi.org/10.1016/j.supflu.2015.12.014

[131] Wilson, A. "Nanoparticle Catalysts Upgrade Heavy Oil for Continuous-Steam-Injection Recovery", Journal of Petroleum Technology, 69(3), pp. 66-67, 2017. https://doi.org/10.2118/0317-0066-JPT

[132] Hovsepian, C. N., Ortega, L. C., Pereira-Almao, P. "Laboratory Two-Dimensional Experimental Simulation of Catalytic in Situ Upgrading", Energy \& Fuels, 30(5), pp. 3652-3659, 2016. https://doi.org/10.1021/acs.energyfuels.5b02117

[133] Fedyaeva, O. N., Antipenko, V. R., Vostrikov, A. A. "Heavy oil upgrading at oxidation of activated carbon by supercritical water-oxygen fluid", The Journal of Supercritical Fluids, 126, pp. 55-64, 2017.

https://doi.org/10.1016/j.supflu.2017.02.016

[134] Chao, K., Chen, Y., Liu, H., Zhang, X., Li, J. "Laboratory Experiments and Field Test of a Difunctional Catalyst for Catalytic Aquathermolysis of Heavy Oil", Energy \& Fuels, 26(2), pp. 1152-1159, 2012.

https://doi.org/10.1021/ef2018385

[135] Chen, G., Yuan, W., Bai, Y., Zhao, W., Gu, X., Zhang, J., Jeje, A. "Ethanol enhanced aquathermolysis of heavy oil catalyzed by a simple Co(II) complex at low temperature", Petroleum Chemistry, 57(5), pp. 389-394, 2017.

https://doi.org/10.1134/S0965544117050036

[136] Li, J., Chen, X., Tang, X., Sun, Y., Liu, H., Deng, L., Wei, Y. "Upgrading heavy and extra-heavy crude oil for transportation by use an iron oil-soluble catalyst", Petroleum Science and Technology, 35(12), pp. 1203-1208, 2017. https://doi.org/10.1080/10916466.2017.1316739

[137] Galukhin, A. V., Erokhin, A. A., Osin, Y. N., Nurgaliev, D. K. "Catalytic Aquathermolysis of Heavy Oil with Iron Tris(acetylacetonate): Changes of Heavy Oil Composition and in Situ Formation of Magnetic Nanoparticles", Energy \& Fuels, 29(8), pp. $4768-4773,2015$.

https://doi.org/10.1021/acs.energyfuels.5b00587

[138] Hamedi-Shokrlu, Y., Babadagli, T. "Kinetics of the In-Situ Upgrading of Heavy Oil by Nickel Nanoparticle Catalysts and Its Effect on Cyclic-Steam-Stimulation Recovery Factor", SPE Reservoir Evaluation \& Engineering, 17(3), pp. 355-364, 2014. https://doi.org/10.2118/170250-PA
[139] Song, S. F., Guo, Z., Bai, Y., Gu, X. F., Chen, G., Zhang, J., Li, B. Q., Zhang, Z. F. "The use of a tartaric-Co(II) complex in the catalytic aquathermolysis of heavy oil", Petroleum Science and Technology, 35(7), pp. 661-666, 2017. https://doi.org/10.1080/10916466.2016.1273239

[140] Chen, G., Yan, J., Bai, Y., Gu, X., Zhang, J., Li, Y., Jeje, A. "Clean aquathermolysis of heavy oil catalyzed by Fe(III) complex at relatively low temperature", Petroleum Science and Technology, 35(2), pp. 113-119, 2017. https://doi.org/10.1080/10916466.2016.1255644

[141] Chen, Y., Wang, Y., Lu, J., Wu, C. "The viscosity reduction of nano-keggin- $\mathrm{K}_{3} \mathrm{PMo}_{12} \mathrm{O}_{40}$ in catalytic aquathermolysis of heavy oil", Fuel, 88(8), pp. 1426-1434, 2009. https://doi.org/10.1016/j.fuel.2009.03.011

[142] Zhao, F., Liu, Y., Fu, Z., Zhao, X. "Using hydrogen donor with oil-soluble catalysts for upgrading heavy oil", Russian Journal of Applied Chemistry, 87(10), 1498-1506, 2014. https://doi.org/10.1134/S1070427214100164

[143] Wu, C., Su, J., Zhang, R., Lei, G., Cao, Y. "The Use of a Nano-nickel Catalyst for Upgrading Extra-heavy Oil by an Aquathermolysis Treatment Under Steam Injection Conditions", Petroleum Science and Technology, 31(21), pp. 2211-2218, 2013. https://doi.org/10.1080/10916466.2011.644016

[144] Hou, J., Li, C., Gao, H., Chen, M., Huang, W., Chen, Y., Zhou, C. "Recyclable oleic acid modified magnetic $\mathrm{NiFe}_{2} \mathrm{O}_{4}$ nanoparticles for catalytic aquathermolysis of Liaohe heavy oil", Fuel, 200, pp. 193-198, 2017. https://doi.org/10.1016/j.fuel.2017.03.005

[145] TotalEnergies, "Chemical Enhanced Oil Recovery (CEOR): an Ever-Growing Field of Application", [online] Available at: https://www.ep.total.com/en/expertise/reservoir/chemical-enhanced-oil-recovery-ceor-ever-growing-field-application [Accessed: 25 April 2020]

[146] Sheng, J. J. "Investigation of alkaline-crude oil reaction", Petroleum, 1(1), pp. 31-39, 2015. https://doi.org/10.1016/j.petlm.2015.04.004

[147] Shell Petroleum Development, "Hydrocarbon recovery optimization", [online] Available at: https://www.shell.com/ energy-and-innovation/overcoming-technology-challenges/ making-the-most-of-ourresources/_jcr_content/par/textimage.stream/1462800199005/79f4638ac5b75bdbd4c04c0b4dd2668051648ecb/eor-brochure-2016.pdf [Accessed: 25 April 2020] 